\title{
Dried Melon Production Line
}

\author{
Iskandarov Zafar, Saidkhujaeva Nafisa, Irmuxamedova Ludmila
}

\begin{abstract}
The article discusses the principle of building a technological line for the production of dried melon, based on a number of developed and approved technical means: machines for cleaning the melon from the peel, a unit for cutting melons into ring slices, a chamber-chain drying unit and other flexible technological systems providing an integrated approach and continuity of production. Presents some results of experimental studies showing the effectiveness of the proposed production process line melting melon.
\end{abstract}

Keywords: melon, bark, clearing, mechanization, cutting, part, dried, disk knifes, packing, container.

\section{INTRODUCTION}

One of the most important tasks of our time is to improve the supply of the population of the country throughout the year with high vitamin, nutritious, environmentally safe food, in particular, melons. The solution of this task should be carried out by applying the latest achievements, of science in the field of agricultural technology, regionalization and use of promising varieties and hybrids, adapted to the conditions of the region, the use of effective and promising technical means, improving the composition, flowability and manufacturability of the lines in particular the storage and processing to improve the quality and reduce the loss of products, at minimum cost, which will significantly eliminate the prep that adopt economically rational and economic solutions in agricultural production.

The solution of this task should be carried out by applying the latest achievements of science in the field of agricultural technology, regionalization and use of promising varieties and hybrids, adapted to the conditions of the region, the use of effective and promising technical means, improving the composition, flowability and manufacturability of the lines in particular the storage and processing to improve the quality and reduce the loss of products, at minimum cost, which will significantly eliminate the prep $\mathrm{t}$ hat adopt economically rational and economic solutions in agricultural production.

In order to compensate for the consumption of melons and especially throughout the entire calendar year to scientifically based standards, it is necessary to ensure yearround consumption in addition to increasing its production. This problem can be solved by increasing the production of high-quality dried (dried) melon, which can be consumed during the entire calendar year, including in winter.

Revised Manuscript Received on July 18, 2019.

Iskandarov Zafar, Tashkent state agrarian university, Tashkent, Uzbekistan.

Saidkhujaeva Nafisa, Tashkent institute of irrigation and agricultural mechanization engineers, Tashkent, Uzbekistan.

Irmuxamedova Ludmila, Tashkent institute of irrigation and agricultural mechanization engineers, Tashkent, Uzbekistan.
To solve this problem, firstly, it is necessary to grow a high-quality melon crop. Then it is necessary to provide high-quality storage of the harvested crop. Finally, it is necessary to develop a production melon fruit processing line.

Central Asian varieties of melons are well known not only in our republic, but also deserve special attention in the CIS and other countries abroad. Natural - climatic conditions of Uzbekistan allow to cultivate and grow the variety vysokosaharisty varieties of melons, among which the most widely used are: pineapple, Gulab, Shakar - Palak, zarchapan, Ich - Dogwood, Bukhara, Amiri, Mirzachul, Chogare, Kaybashi, Ditma, Bori - Calla , Tsarvaki et al. $[1,2,3]$.

Melons contain high amounts of sugar, carbohydrates, essential oils, fiber and micronutrients. They are very useful for human life and are a storehouse of various vitamins. Melons are consumed mainly in fresh form, but they also come for technical processing, including preparing jam, jam, honey melon (pekmez), and - vyalyat.

Yields melon is very high and reaches up to 400 quintals per hectare. This culture does not require copious irrigation and can be grown in saline soil areas. In 2015, the crop area of the country amounted to more than 60 thousand hectares, and the volume of harvest exceeded 1 million tonnes, while the production of dried melon was about $90-. .100$ thousand tons.

Sun-dried melon engaged mainly in the home, small farms and private dehkan monastery, using mainly manual labor. The technology is based on air - drying process sunlight, often without observing sanitary - hygiene standards and it depends on weather conditions and as a result the quality of the final product does not meet the specifications and requirements [3].

The aim of our study researches a comprehensive approach to solving this problem and the creation of mechanized flow production line for waste-free processing and drying of melon fruit, suitable for operation in the conditions of small farmers.

On the basis of patent - litsentsionnyh surveys and performed theoretical and experimental - experimental studies, we have developed hardware - technological scheme of the complex flow production line for the production of dried melon (Figure 1). 


\section{DRIED MELON PRODUCTION LINE}

\section{RESULTS \& DISCUSSION}

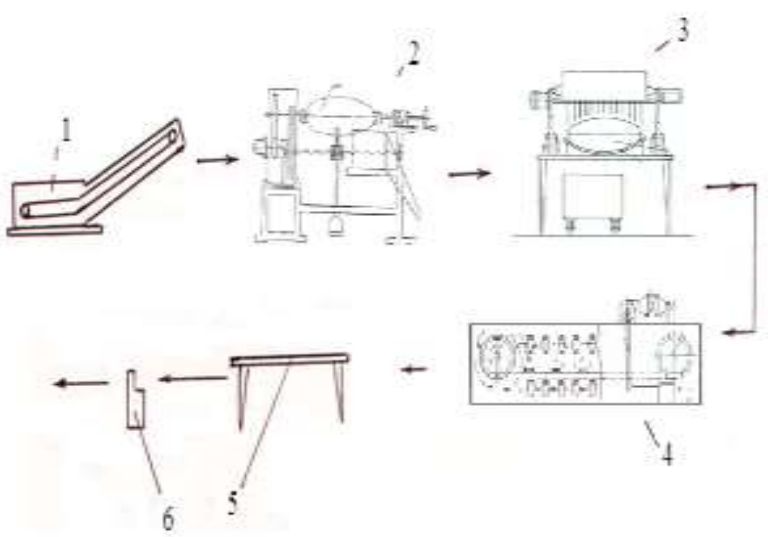

Fig.1. Instrumental technological scheme of the integrated production line-technological line for the production of dried melon.

1-washing machine; 2-peeling machine; 3-device for cutting the melon fruit into ring slices; 4-chamber chain drying unit; 5-inspectoin table; 6-weighing packing unit.

The line includes a set in a specific order on the upstream side rinsing belt - chain washer 1, the unit 2 for removing rind melon, apparatus 3 for cutting a melon fruit into ring segments, chamber - chain drying unit 4 , an inspection table 5 and razvesochno - packaging unit 6 .

The line is as follows. Melon after washing and rinsing is fed to the machine for removing the rind 2 . The principle of its operation is based on turning melon surface dvuhlezviynom floating cutter, which is controlled by a smooth pressing the pedal, so that the cutter traverses multiple curved (spindle) surface melon. More in detail the operating principle is described in [4].

The proposed device has several advantages compared with manual cutting melon. First, the presence of a curvilinear lodgement does not require any fixing devices for fixing the processed melon. A pack of disc knives of various sizes in diameter allows to obtain these slices in a wide range of ring widths, depending on the type of dried melon. Swivel frame with automatic lifting of the cutting body reduces the interoperative time spent by the staff, contributes to increasing productivity and production culture.

An important step in the production of dried melon is the process of drying it. The national method of drying on hangers does not meet the technical conditions and therefore we have developed a chamber-chain drying unit [2].

According to the description, an experimental sample of the drying unit was made. The overall dimensions of the installation were: length - $3000 \mathrm{~mm}$, width - $600 \mathrm{~mm}$, height - $700 \mathrm{~mm}$. Electric air heater PGS-018T was used as the air heater, power consumption - $8 \mathrm{~kW}$ (Producer - Ph.F. "Taschelectroapparat"). Fan VTs-4-70 No. 5 with adjustable throttle, setting power $-1.5 \mathrm{~kW}$. IR - radiators of the KGT 220-500 brand, spectral range $0.8 \ldots 2.8$ microns. 6 pieces were installed. emitters complete with reflectors.

One-time loading in the dryer was $120 \mathrm{~kg}$ melon pulp samples at different thicknesses: 15,18,20 mm. Drying modes: the air temperature in the initial period $=70-800 \mathrm{C}$ at the end of drying $=55-60$ 0C.The heat flux density varied in the range of $\mathrm{kW} / \mathrm{m} 2$, the air velocity in the chamber was $\mathrm{Vb}=4.2 \mathrm{~m} / \mathrm{s}$.

Drying of melon was performed to a final humidity $\mathrm{W}=$ $19-20 \%$. The yield of finished products was $19.5 \mathrm{~kg}$. drying time -30.5 hours.

Taste and smell typical of dried melon - sweet, slightly sugary. Color light yellow, straw. Consistency in the same section of lobes, under strong pressure from the juice they are released.

Jerky melon inspect removed caramelised portions and twisted into braided tows, and then hung on 500-100 g, are placed in cellophane bags and sent to a warehouse for storage or retail trade.

Thus, due to the inclusion of a serial in-line processing line number of machines and apparatuses providing mechanization processes melon fruit processing and use of energy-saving design convective dryer as well as the use of other flexible manufacturing systems is achieved by:

- Reduction labor intensity of preparatory operations;

- increase dried melon production per unit of useful area exploited;

- increase the quality of the finished product due to the organization of intensive air in the drying process;

- the possibility of extending the calendar dates of melon processing, including the winter months (such as the varieties of melons "Gulab", "Storm Calla", "Horazemsky" and others. stores until February, the month of March).

In conclusion, it should be noted that the duration of melon 30-32 hours of drying, in-line process line can be equipped with three dryers. In this seasonal production (September - December) of the finished product will be more than 43 tons [4].

In conclusion, it should be noted that when the proposed production line is used by farmers, it is expected to obtain a tangible economic effect by replenishing the assortment of original products, eliminating losses, also protecting the environment and ensuring safe working conditions for service personnel.

\section{REFERENCES}

1. Z.Iskandarov, G.Abdieva, N.Saidkhujaeva M.Karimullaeva. Machine for cutting melons on ringsheeds. International Journal of Advanced Research in Science, Engineering and Technology Vol. 6, Issue 4, April 2019 ISSN: 2350-0328.

2. Z.Iskandarov, G.Abdieva, N.Saidkhujaeva, M.Karimullaeva, M.Matyakubov. Experimental investigation of the thermophysical characteristics of the melatic meat. Actual problems of modern science, education and trainining. 2019-II. ISSN 2181-9750.

3. Целевая оценка плодов дыни (Методика) Текст. /В.В Коринец, Т.А. Санникова, В.Н. Самодуров. Астрахань: ООО «Типография «Нова», 2006. - 27 с.

4. Магомедов Р.К. Научно-практические основы транспортирования и хранения скоропортящихся овощей Текст. / Р.К. Магомедов. М.: ФГНУ «Росинформагротех», 2009. - 200 с.

5. Z.Iskandarov and other. № FAP01240 "Chamber chain drying unit for agricultural products" 
6. N.Saidkhujaeva. "Механизированный очиститель плодов дыни от кожуры”. «Итоги и перспективы развития агропромышленного комплекса» материалы международной научно-практической конференции. с. Соленое Займище.- 2018. - 655 с. 